Document downloaded from:

http://hdl.handle.net/10251/119578

This paper must be cited as:

Sanz Martínez, D.; Vos, J.; Rambags, F.; Hoogesteger, J.; Cassiraga, EF.; Gómez-Alday, JJ. (2018). The social construction and consequences of groundwater modelling: insight from the Mancha Oriental aquifer, Spain. International Journal of Water Resources Development. 1-22. https://doi.org/10.1080/07900627.2018.1495619

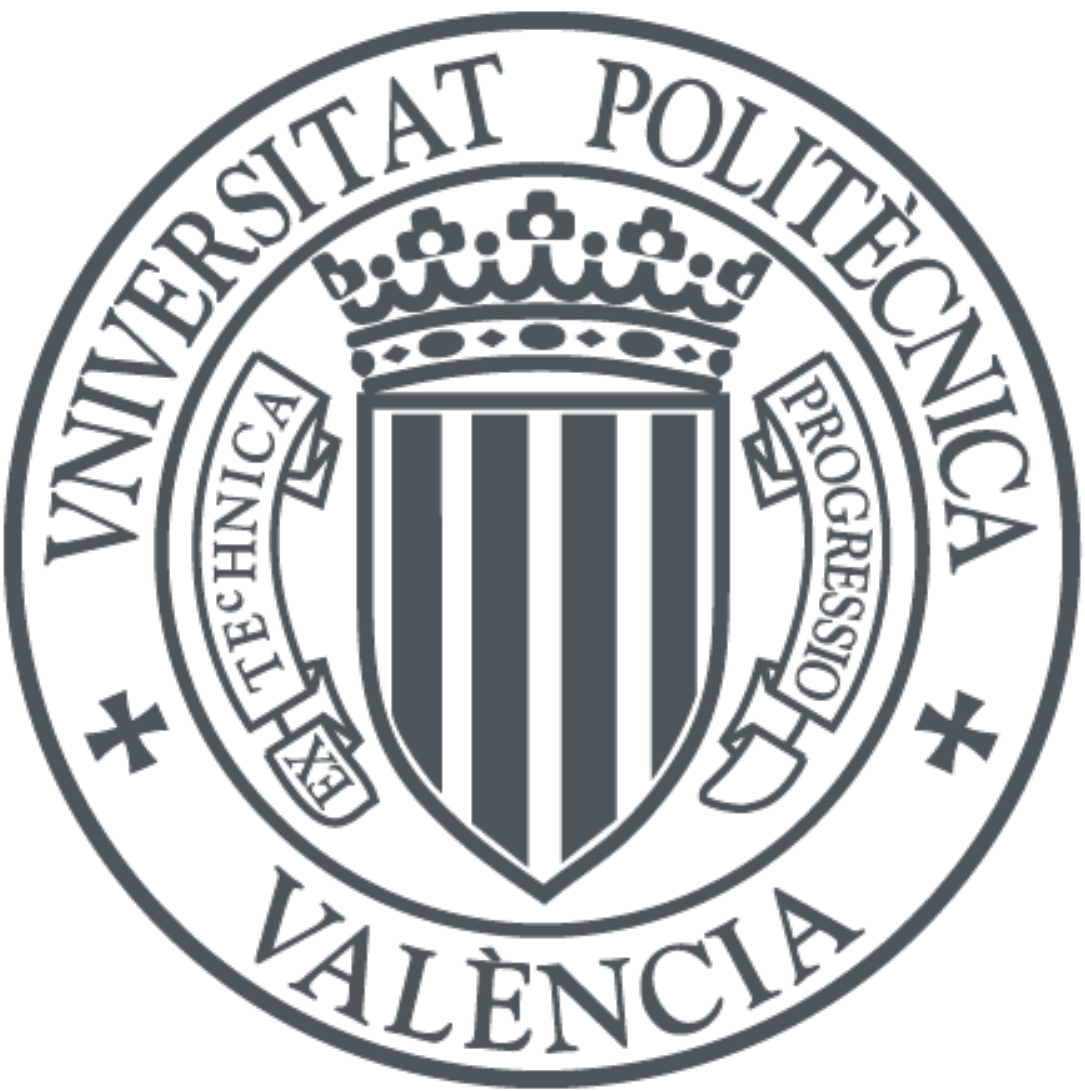

The final publication is available at

http://doi.org/10.1080/07900627.2018.1495619

Copyright Taylor \& Francis

Additional Information 


\section{The social construction and consequences of groundwater modelling: insight from the Mancha Oriental aquifer, Spain}

David Sanz ${ }^{1}$, Jeroen $\operatorname{Vos}^{2}$, Femke Rambags ${ }^{3}$, Jaime Hoogesteger ${ }^{2}$, Eduardo Cassiraga $^{4}$, Juan José Gómez-Alday ${ }^{1}$

${ }^{1}$ Hydrogeology Group. University of Castilla-La Mancha (UCLM). Albacete, Spain

${ }^{2}$ Water Resources Management Group, Wageningen University; Wageningen, the Netherlands

${ }^{3}$ Department of Earth and Ocean Sciences, The University of Waikato; Waikato, New Zealand

${ }^{4}$ Hydraulic and Environmental Engineering Department, Universitat Politècnica de València; Valencia, Spain

Corresponding author: David Sanz; David.Sanz@uclm.es, Tel.:+34 967599200 


\begin{abstract}
Groundwater flow models have been increasingly used to support policy making. A substantial amount of research has been dedicated to improving, validating and calibrating models and including stakeholders in the modelling process. However, little research has been done to analyse how choices of model makers and steering by policy makers result in models with specific characteristics, which only allow for specific modelling outcomes, and how the use of these modelling outcomes leads to specific social, economic and environmental consequences. In this study, we use the social construction of technology (SCOT) framework to explore the development, characteristics and uses of the groundwater model of the Mancha Oriental aquifer in Spain. The specific characteristics and functioning of this model influenced the policy implementation, implying that involving stakeholders in the development and use of models is crucial for improved democratic policy making.
\end{abstract}

Keywords: Groundwater governance, Modelling, Model-based policy-making, SCOT, Spain 


\section{Introduction}

The increased exploitation of groundwater has led to aquifer depletions around the world, which has caused urgency in the governance of sustainable groundwater use (Burke \& Moench, 2000; Hoogesteger \& Wester, 2015; Jakeman et al., 2016; Konikow \& Kendy, 2005; Tortajada, 2010; Vaux, 2011). To support water managers and government processes more broadly, a substantial amount of effort has been devoted to the development of groundwater models to support decision-making in policy design. Models are considered to be ideal tools that simulate the behaviour of complex surfacegroundwater systems and interactions (Hill et al., 2015; Refsgaard \& Henriksen, 2004). Although groundwater flow modelling is a simplification of reality by definition, it has proven to be useful in providing information about the behaviour of hydrogeological systems and supporting decision-making (Doherty \& Simmons, 2013). As a result, modelling has gained importance in the water control domain. Modelling depoliticizes policy making by invoking ideas of evidence-based policies and environmental accounting, which are often promoted as part of integrated water resources management (GWP, 2000; Wester et al., 2009) and river basin planning in the European Water Framework Directive (EC, 2000).

Models are often seen as neutral tools that help policy makers in making decisions. However, models are not neutral, as the specific characteristics of a particular model allow only for certain uses and certain modelling outcomes. The use of a particular model will influence policy outcomes and implementation and thus have specific social and economic impacts for certain groups in society and produce specific environmental impacts. Moreover, the use of a model might provide legitimacy to policies and influence perceptions of people about certain issues. 
The neutrality and objectivity of hydrological models are often not questioned. Models are created based on deliberate choices and conscious and unconscious assumptions by the model commissioners and model developers. Models are often created to respond to specific policy questions and demands. The scoping of the problem and the modelling choices imply an enormous simplification in the representation of the complex reality, excluding many factors, processes, parameters, geographic areas, and time periods that might be relevant for certain groups in society (or future generations). In this sense, models and the model outcomes are not "neutral" but rather "political" (King \& Kraemer, 1993). Moreover, the use of the specific results of models in policy making has economic distributive effects (i.e., some stakeholders win, and some lose) and environmental consequences. Thus, models, beyond the political intention of policymakers, have social, economic and environmental effects via the intrinsic characteristics and functions of the models themselves.

Previous research has shown that groundwater models are formed by developers who a) have specific knowledge and preferences, b) are often influenced by funding and funders, c) consider only specific parameters, spatial resolution, factors, variables, geographic areas and time scales (calibration period), d) perform calculations in a certain manner for specific (policy) purposes, and e) base the models on limited data sets (Beven, 2000; Konikow \& Bredehoeft, 1992; Melsen et al., 2018; Molle, 2008). This recognition has led to a substantial amount of effort directed towards the development of participatory agent-based modelling as a means to broaden the foundation on which decisions are made. Past experiences indicate that involvement of stakeholders in the modelling process allows stakeholders to become aware of the complex hydrogeological systems and their dynamics, in addition to serve as a collaborative learning tool for the identification of impacts (Castilla-Rho, 2017; Voinov \& Bousquet, 2010). Despite these 
advances, important questions remain regarding the role that hydrological models play in policy making and implementation, especially because model outcomes are often portrayed in policy-making processes as an objective and unquestionable reality that is used to make well-informed (political) decisions, and the model itself remains a black box. To understand this black box and its social, economic and environmental effects, we analyse a model used in the Mancha Oriental aquifer of Spain to understand a) how hydrogeological models are socially constructed; b) the specific characteristics and functions of the model; c) the use of models to legitimize policies and political choices; and d) the socio-economic, political and environmental effects of the use of these models.

We use the concept of the social construction of technology (SCOT), in which groundwater models are viewed as a technology that is socially constructed and whose use has social consequences (Bijker et al., 1987; Bijker et al., 2012). Nevertheless, simply stating that models are not black boxes, that they are socially constructed and that they have social, economic and environmental effects leaves many questions regarding how the inner workings of a model are formed and what the effect of this technology on society is (Winner 1993). We attempt to gain insight into these questions by analysing one modelling project in the Mancha Oriental aquifer (MOA). The MOA is an extensive groundwater body located in the semiarid Júcar River basin in Spain (see Figure A1). Intensive groundwater use has led to decreases in piezometric levels and has generated social and environmental problems that have led to conflicts between ground and surface water users, environmental groups, water managers and policy-makers in the river basin. As part of a joint effort to improve water management and reduce conflict, a hydrological/groundwater model was constructed and used for policy making, which we analyse here.

\footnotetext{
Figure A1 near here
} 
This article is based on fieldwork performed by the third author from August to October of 2013, which was supervised by the first and second authors (see Rambags, 2014). Open-ended semi-structured interviews were conducted with stakeholders, including water authorities. The interviews were used as a tool to collect factual data and reconstruct interpretations and perceptions regarding the development and use of the MOA model. The Spanish authors of the article were involved in the development of the MOA model in the period from 2010 - 2014. During the period from 2014 to 2017, they were involved in the use of the model for different applications during simulated scenarios, such as replacing groundwater pumping with surface water and predicting the effects of climate change on the water system.

\section{Analysing models through SCOT}

Although groundwater flow modelling is a simplification of reality by definition, it has proven to be useful for providing information about the complex behaviour of hydrogeological systems and supporting decision-making (Doherty \& Simmons, 2013). In most social science studies, a model is treated as a black box. Groundwater models are understood only in terms of their inputs and outputs, regardless of the internal and technical operations of the model. The natural sciences usually concentrate only on the computational workings of a model, assuming that the computational functions of the model are based on the application of scientifically proven methods and rational decisionmaking by modellers. These views ignore the fact that the characteristics (the model configuration with spatial representations of forcing data, parameters, spatial resolution, etc.), functions, visualizations of output and uses of models are shaped by model makers who make their own choices and have many conscious and unconscious assumptions 
about what is important and what can be left out of the model (Bijker et al., 2012, Melsen et al., 2018).

The SCOT approach assumes that there is no predetermined logic in the technological development of the model but rather that the development of the technology depends on the social actors who are influenced by relevant social groups. Therefore, the development of this technology results from choices and contingencies that are inherent in the design process. Thus, there are different paths of technology development that potentially lead to different technological results. Technological development is therefore conceptualized as path-dependent and emergent.

A groundwater model is a conceptual and mathematical representation of a real groundwater system (Anderson et al., 2015). To analyse groundwater models, we suggest that these models have a structure that is formed by a set of factors (e.g., inputs, computational relationships, parameters and outputs/outcomes) (Figure 2), and choices are made regarding those factors, which lead to specific model outcomes that, in turn, have social, economic and environmental consequences when used in policy making. Apart from standard modelling practices and practical feasibility, these choices depend on factors such as the objectives of the model, its desired outcomes, the stakeholders involved, data availability and time, funding and the expertise of the model makers.

Figure 2 near here

Discussions about the choices made during modelling are ongoing amongst modellers, but they are rarely considered to have social implications. Rather, most of these debates are framed as debates that are related to the accuracy of the model outcomes and the degree of detail required in the outcomes. Model makers might also complain about the misinterpretation, political use or incorrect use of their model results by policy 
makers or other stakeholders, but they rarely consider the model itself to be partial or biased or that it can steer political discussions in a particular direction. The most common decisions made by groundwater modellers concern variables that are used during spatiotemporal discretization and grid design, such as the boundary conditions of the system's elements (e.g., recharge capacity, rivers, lateral flow, and lakes) and external actions (e.g., groundwater pumping). In modelling, aquifers can be characterized by their hydraulic parameters (e.g., hydraulic conductivity, transmissivity, and storativity). The calculation methods imply choices regarding numerical solutions (using either a finitedifference method or a finite-element method) and solution methods for linear equations (i.e., the type of solver). Additionally, choices are made regarding model complexity. For example, a complex hydrogeological structure is simplified to a limited number of clearly defined aquifers, and climate change might not be considered. Although hydrological models can vary in their degree of complexity, there is disagreement about whether their performance varies accordingly. For instance, Voss (2011) argues that many hydrological models include unnecessary and complex calculations to resemble physical processes, when it would be much more effective to use simple water balances to match the input and output data. In contrast, Massuel et al. (2011) argue that hydrological models should be modelled based on the very specific physical circumstances of a site. They show that, for example, the rainfall - infiltration relationships can be very location-specific, and large errors can occur when general equations are used. Likewise, there are serious concerns about calibration and validation processes not resulting in a reliable predictive capability in long-term models (Konikow \& Bredehoeft, 1992). Additionally, the presentation formats of the calculation outcomes imply choices that represent reality and show uncertainties in the outcomes of the calculations. 
In addition to these technical discussions, from a SCOT perspective, model development is considered to be dependent on relevant social groups (Bijker, 1987). Relevant social groups are groups of people that share a particular vision and understanding regarding a certain object or process. For example, the perception of groundwater models by scientists may be linked to the underlying scientific concepts contained in the model, whereas farmers' perceptions may be linked to their assessments of the utility of the model to address a theme with which they are concerned. Policy makers that commission the development of a hydrological model focus on certain parameters and model purposes. In this manner, the commissioners steer the development of the model in a certain direction. The model is therefore culturally constructed and interpreted. There is flexibility not only in how a model is designed but also in how people think about or interpret it; this is called interpretive flexibility. During the development process of a technology, the interpretations of different groups tend to converge. This process is known as the stabilization or closure of interpretive flexibility.

The interaction between groundwater models and social groups is studied by analysing what in SCOT theory are called the social requirements for use of a particular technology. The in groundwater modelling social requirements for use refer to the characteristics (structure, time and spatial scales and resolutions, etc.) of the model and what functions it can perform. The social requirements for use also refer to the question of who has the knowledge and skills to use the model and who can interpret the outcomes of the model use (Narain \& Singh, 2017). Hydrological models steer policy debates based on the outcomes they generate and the way they are visualized; they set the agenda for policy discussions emphasizing certain aspects while neglecting other aspects. At the same time, they legitimize policies based on the model outcomes. 


\section{The Mancha Oriental aquifer: characteristics and use}

The MOA is one of the most extensive aquifers in southern Europe $\left(7,250 \mathrm{~km}^{2}\right)$, and it is located in eastern Spain and belongs to the Júcar River basin (see Figure A1). The area has a continental, semi-arid climate that reaches extreme temperatures in both winter and summer, with average monthly temperatures of $6^{\circ} \mathrm{C}$ in winter and $22^{\circ} \mathrm{C}$ in summer. The average precipitation is approximately $350 \mathrm{~mm} / \mathrm{yr}$ and ranges from $280 \mathrm{~mm} / \mathrm{yr}$ along the southern boundary to $550 \mathrm{~mm} / \mathrm{yr}$ in the northern zone, with notable interannual variations. The potential evapotranspiration of the reference crop (Festuca arundinacea - forage grass) is approximately $1,200 \mathrm{~mm} / \mathrm{yr}$.

The surface is a nearly flat plain (700 metres above sea level) that is interrupted only by the valley excavated by the Júcar River. The MOA is a multi-layered karstic system formed by the superposition of nine hydrological units, where the aquifer units from the middle Jurassic, upper Cretaceous and middle Miocene are separated by aquitards and aquifuges. The impermeable bottom layer of the system is composed of lower Jurassic (and occasionally Triassic) marls, clays, and gypsum. A more complete description of the aquifer and the conceptual model built for its understanding can be found in Sanz et al. (2009).

Under natural conditions, the Júcar River is the main groundwater discharge element in the MOA. The natural recharge is derived from rainwater infiltration, lateral groundwater inflow, and infiltration from the Jardín and Lezuza rivers and wastewater from the city of Albacete.

The Alarcón reservoir, with a total capacity of 1,118 million $(\mathrm{M}) \mathrm{m}^{3}$ (during the last 10 years (2008-2018), the water level has not surpassed $50 \%$ of its capacity), regulates the Júcar River (Figure A1). The river flow produces hydroelectrical power and supplies water to irrigated croplands in the Valencia plain and the populations of Albacete and 
Valencia (170,000 and 1,000,000 inhabitants, respectively). The flow in the Júcar River is notably seasonal, with the largest flows occurring during autumn and the weakest flows occurring during the summer months. The Tajo-Segura transfer (140 km length) crosses the MOA from north to south but has no direct contribution on the aquifer storage due to its impermeable lining. Indirectly, the transfer recharges the aquifer through water use from this channel, which has replaced groundwater for irrigation since 2001 (Figure A1).

In the mid-1960s, the importance of the MOA as a groundwater body was discovered, and the extractable volume was estimated to be approximately $300 \mathrm{Mm}^{3} / \mathrm{yr}$. Its use made it possible to irrigate large areas. This fact not only was recognized by the scientific community but also reached the general public through magazines and newspapers with headlines such as "Albacete has an authentic ocean of water in the subsoil" (Pueblo newspaper, 5 July 1974). At that time, accessible drilling techniques and submersible pumps were introduced in Spain, which allowed for groundwater irrigation by private investors in large areas that led to intensive and often unregulated groundwater use.

Because of its atomistic and individualized character, regulating the overpumping of groundwater has become a serious challenge in Spain and elsewhere around the world (Giordano, 2009; Hoogesteger \& Wester, 2017). According to the Spanish Water Law of 1985, water authorities should authorize and register new groundwater wells. However, control and management have been complicated due to the lack of administrative resources for water authorities (Júcar River basin Authority; in Spanish, Confederación Hidrográfica del Júcar, CHJ), especially during a critical period (19851988), when groundwater exploitation was more widely developed due to the application of national agricultural expansion policies without clear knowledge of the water resource availability in many river basins. As an element that supports aquifer management, the 
association of groundwater users, the JCRMO (in Spanish, the Junta Central de Regantes de la Mancha Oriental), was created during that period. The JCRMO was created as a public corporation based on the provisions of the Spanish Water Law, and they participated with water authorities to develop exploitation plans and sanction infractions through a jury that specializes in irrigation (Lopez-Gunn, 2003; Sanz et al., 2016).

In this context, over the last 30 years, approximately $1,000 \mathrm{~km}^{2}$ of irrigated lands became dependent on groundwater, which allowed for significant socioeconomic development in the area. From the hydrological year 2006/07, approximately $320 \mathrm{Mm}^{3} / \mathrm{yr}$ of groundwater is pumped, of which $98 \%$ is used for agriculture. The volume extracted exceeds that of the natural recharge, which is estimated at $260 \mathrm{Mm}^{3} /$ year (Júcar River basin Management Plan; CHJ, 2014, 2016). The intensive exploitation of groundwater coupled with droughts, such as that in the early 1990s (1990-1994), has led to significant decreases in piezometric levels (by approximately 80 metres in some areas) and the volume of stored groundwater, in addition to a decrease in the contribution from the MOA to flows in the Júcar River (Figure 3). The water in the Jucar river is used downstream of the MOA for two important irrigation systems: the Jucar-Turia and La Acequia Real del Júcar irrigation systems (in total some 47,000 ha with some 60,000 farmers), the city of Valencia, and the Albufera wetland, important for rice farming, tourism and fishing.

The resulting scarcity has generated social and environmental problems that have led to conflicts regarding access to water resources among groundwater users in the Mancha Aquifer (JCRMO), surface water users in the downstream Valencia area, environmental groups, water managers $(\mathrm{CHJ})$ and policy-makers in the Castilla - La Mancha and Valencian regions.

Figure 3 near here 
In 2002, the Júcar River basin (including the hydrogeological system of the MOA) was designated one of the pilot basins for the implementation of the Water Framework Directive (EC, 2000) in Spain. The MOA was considered to have a poor status by the CHJ at that time. Therefore, a programme of measures had to be established in the Júcar River Basin Management Plan (CHJ 2014, 2016). During this period, the CHJ and JCRMO were made responsible for the joint management and monitoring of the MOA through the Aquifer Exploitation Plan and the related Júcar River Basin Management Plan (2009-2015, 2015-2021). In the Aquifer Exploitation Plan, stakeholders set the authorized volume per hectare, and the CHJ-JCRMO monitored groundwater use (using remote sensing techniques; Calera et al., 2017) to not exceed the allocated volume.

\section{Making modelling part of the policy process in the MOA}

The CHJ is responsible for hydrological management and planning in the Júcar River basin. In 2006, the CHJ and JCRMO deemed it necessary to establish a tool for decisionmaking that could be used for the programme to temporarily buy groundwater use rights; later, this model was also used for planning processes in the Júcar River Basin Management Plans (2009-2015 and 2015-2021). This tool would be available for water management authorities (i.e. policy makers) and those interested in the direct use of water, such as farmers. It was deemed imperative for the policy making process to have more credible and reliable information about the water balance, river-aquifer relationships and related environmental effects for stakeholders, managers and the general public. Moreover, the model should be developed and validated by independent scientists. Given the existing tension in the MOA/Jucar River basin, an agreement was established among water users, water managers and researchers to develop a groundwater model that would clarify the hydrological relationships between the MOA and the Júcar River. 
In 2006, the CHJ established a collaboration agreement with the JCRMO and the universities of Castilla-La Mancha and the Politècnica de València to develop a groundwater/hydrological model of the MOA. Because of the tension between upstream and downstream water users in the Júcar watershed (i.e., groundwater users in the Mancha Aquifer (JCRMO) vs. surface water users in the Valencia area), it was decided that the model should be jointly developed by researchers from both a university located downstream (Valencia) and one located upstream (Albacete). The CHJ and JCRMO believed that the collaboration agreement, which ensured the participation of all parties, would result in the development of a model that would be widely accepted and validated by the relevant social groups while also increasing the legitimacy of the choices made by the CHJ and JCRMO.

The main goal of the model was to investigate the relationship between groundwater extraction and hydrological flow in the Júcar River (Cassiraga et al., 2013). For the CHJ-JCRMO, the model has multiple purposes: (a) to enhance the understanding of groundwater systems and their interactions with surface water, (b) to be used as a tool to make predictions regarding the response of the systems to the proposed policies, (c) to be used as a decision support tool for the management of the MOA, and (d) to be used as a visualization tool for communicating with society. University researchers considered the model mainly as an interpretative tool for investigating groundwater system dynamics and understanding flow patterns.

The JCRMO and CHJ initially delegated all model development tasks to the university researchers. Work meetings with researchers from both universities and technical staff from the CHJ and JCRMO were held to select the various inputs, their computational relationships, the parameters and outputs (see Table 1), which led to the closure or stabilization of the model. Table 1 summarizes how different relevant social 
groups influenced the development of the model. The final MOA model was constructed in MODFLOW (Harbaugh et al., 2000) using the Visual MODFLOW version (Waterloo Hydrogeologic Inc., version 4.2) (see Sanz et al., 2011 for further details). The choice to use MODFLOW resulted from the specific functional requirements asked for by CHJ. The choice of MODFLOW enabled specific characteristics of the model but also limited the possible functionalities.

\section{The scientific development of the MOA model}

The model was developed as a regional model. The study area was divided horizontally into $1 \mathrm{~km}^{2}$ cells, which were aligned from north to south to form a grid of 126 columns and 131 rows. This grid of $1 \mathrm{~km}^{2}$ cells was considered the minimum size required to allow a heterogeneous medium, such as karstified limestone, to be modelled as a homogeneous porous medium. As a result, the model could only be used to simulate regional groundwater conditions and groundwater/surface water interactions. This decision affected how the model could be used (i.e., the social requirements for use). The model could not, for instance, be used to assess the effects of groundwater extraction by a single farmer on the local groundwater table or flow in the Júcar River. Additionally, because the model discretization is $1 \mathrm{~km}^{2}$, aquifer-river relations could be analysed more confidently between distant river sections (e.g., between gauging stations that are more than $30 \mathrm{~km}$ apart) and not on a small scale since the width of the riverbed does not exceed $200 \mathrm{~m}$.

The model incorporated the 3D geometry of the hydrogeological units, which resulted in a model with six layers (three aquifer units and three semipermeable units). This decision was made in agreement between JCRMO and CHJ technicians and researchers from the universities. One of the main reasons for choosing this geometry was 
that it would be easy to visualize and explain to stakeholders. It was therefore expected that such an approach would be readily accepted by all stakeholders. However, this did not mean that the built-in conceptual model was valid and reliable, and therefore free of uncertainty. In contrast, different conceptual models can be constructed from the same field data depending on the interpretation of the hydrogeological modelling team. Each conceptual model produces a different numerical model that will behave differently as a result. The choices of the modelling team itself have effects on the results.

The analysis periods were monthly because data along the boundary conditions were not available at smaller time intervals. Additionally, the objectives of the investigation did not require information regarding the time required for a system to respond to new stresses or the response of the system between periods of relative equilibrium. Nevertheless, more detailed stress periods (e.g., daily) or less detailed stress periods (e.g., annual resolution) could have been selected. The choice of the former would generate much more information, but with a greater degree of uncertainty. In the case of quarterly, semi-annual or annual time scales, the computational requirements would decrease, but decision-making would be for longer time periods, implying that the water authorities would not have an instrument for short-term planning and to respond to more immediate problems.

The boundary conditions were defined by matching the boundaries of the model with the physical boundaries of the system. For example, the Jucar River was represented as a head-dependent boundary condition, and the remaining limits were defined as either no flow or a fixed-flux. In this sense, the hydraulic relationship between the MOA and other aquifer systems was known (Sanz et al., 2011); this corresponded to the watershed between the basins of the Jucar and Guadiana rivers, which is also a groundwater divide. This last boundary condition is subject to temporal changes due to groundwater extraction 
on both sides of the boundary; therefore, the net lateral flow must be estimated from the hydraulic head measurements from the wells located on both sides. The establishment of a fixed-flux condition between both basins ensures model stability, but it can influence the results of the model.

Precipitation recharge values were obtained by applying the Patrical model (Pérez 2005). Recharge from infiltration was used as the spatiotemporal quantifier for the amount of water that reached the saturated zone and was subject to great uncertainty. In fact, it was typically one of the parameters used for calibration of the groundwater model. Nevertheless, since the Patrical model was used as a reference for the entire Júcar River basin, the data from this model were introduced in the MOA model as a fixed quantity without any uncertainty.

The best method to obtain data for groundwater extraction would be to obtain accurate data from metres placed in each of the wells used in the MOA. However, there are thousands of boreholes, many of which are not even registered, and few have operational flow metres. Therefore, an indirect method had to be used. Groundwater pumping for irrigation was determined through a multitemporal and multispectral analysis of Landsat TM images using the methodology proposed in Castaño et al. (2010). This methodology has been utilized by users, water authorities and regional governments through an annual project called ERMOT (Calera et al., 2017). Every year, a crop map is derived from a multitemporal set of Landsat images that were acquired during the growing season. Additionally, the total amount of water required for each crop during the whole season was derived. The total extraction was estimated from the crop map and the water consumption table.

The estimated water consumption is computed as the weighted sum of the requirements for all crops that are irrigated (e.g., corn, sugar beets, and potatoes), where 
the weight of each crop is proportional to the total area sown for that crop. The problem is that the total area is estimated from the farmers' crop plans, which may be subject to changes that are not reported in most cases, and there may be considerable differences in water requirements from one crop to another. Furthermore, it is assumed that farmers actually apply the water required by the crop. Both assumptions introduce uncertainties in the estimation of the water use, but the model did not take into consideration these uncertainties (Sanz \& Castilla, 2005). Groundwater withdrawals for urban and industrial use are estimated by applying a supply value to the population data for various municipalities (following the technical planning instructions provided in the Spanish legislation).

The model was calibrated in two phases: a steady state and a transient state. The elements for calibration used were the observed vs. the calculated groundwater heads (see further details in Sanz et al. (2011)). Subsequently, the model was validated and recalibrated with a simulation of the system under natural conditions from 1940 to 1975 , and subsurface groundwater pumping conditions spanned the temporal range until the present day. The calibration of the model was considered satisfactory when the model could adequately reproduce the flows circulating throughout different stretches of the river and the piezometric surfaces. Assuming that the parameters of the numerical model were adequately calibrated (to remain unchanged during the simulation), the uncertainty analysis may be justifiably criticized because there was no analysis of the impact of uncertainties on the model outcomes, and the uncertainties in the calibrated parameters were considered to be negligible compared to those of the input data.

Table 1 near here 


\section{Utilizing the model results in policy making}

As discussed in the previous section, the JCRMO and CHJ wanted to use the MOA model as a decision support tool for the management of the MOA. Two cases of the use of the model will be discussed below: 1) the use of the model to delineate the boundaries of the Public Offer for the Acquisition of Water Rights zone and 2) the use of the model to designate areas where groundwater use should be substituted with surface water use.

\section{Public Offer for the Acquisition of Water Rights}

A persistent drought during the period from 2005-2008 created environmental problems in the middle section of the Júcar River (i.e., insufficient environmental flow and water for irrigation supply), which eventually impacted downstream users in the Valencia area, specifically in the La Acequia Real del Júcar irrigation system. Faced with this situation, the objectives of the authorities were to try improve the status of the groundwater body, to improve the environmental flows of the Jucar River, to ensure water demands to the downstream users and to balance and harmonize regional and sectoral development. In these sense, the $\mathrm{CHJ}$ decided to reduce groundwater extraction in the MOA to increase aquifer contributions to the river flow, reach environmental river flow requirements and prevent drying of the river, which had occurred in a previous drought (1994-1996) (Holley et al., 2016). The Spanish Water Law (Article 71 TRLA) enables water authorities to temporarily buy water rights from licensed water users by financially compensating users according to the estimated average missed profit, which is called a Public Offer for the Acquisition of Water Rights. The CHJ wanted to apply this measure during the growing seasons of 2006-2007 and 2007-2008 (Ferrer \& Garijo, 2013). In agreement with the JCRMO, the CHJ established the compensation prices offered during the Public Offer for the Acquisition of Water Rights from 0.19 to $0.25 \mathrm{euro} / \mathrm{m}^{3}$ (Table 2). 
Using this price, the $\mathrm{CHJ}$ calculated a maximum number of hectares that could be compensated based on the funds available. Then, the CHJ wanted the university researchers to use the MOA model to determine the zone where reduction in groundwater extraction would be the most beneficial for increasing river flows in the Júcar River. In other words, they wanted to maximize the effects of the available funds.

Table 2 near here

Based on the requirements of the policy makers, the researchers decided not to model the entire MOA but to focus solely on the policy zone and a perimeter defined by the extension of the middle Miocene aquifer (see BOE no. 312, 20-12-2006) (Figures A1 and A4). This hydrogeological unit was chosen for two reasons: (1) the large number of groundwater extraction wells in the area and (2) the relatively substantial hydraulic connection between the aquifer and the Júcar River. The decision for the model developers to limit the simulations in the middle Miocene aquifer was therefore based primarily on these hydrogeological motives.

The researchers ran the model for 3 and 6 months under continuous pumping conditions to simulate the effects of groundwater withdrawals in this specific area of the MOA on the flow in the Júcar River (Figure A4). The model results were presented via a map with iso-influence lines that indicated the affected volume of the Júcar River as the percentage of the total amount of groundwater extracted at a certain point in the aquifer after 3 or 6 months of pumping. The maps were compiled using results at two different times (after 3 and 6 months) to visualize the change in iso-lines with time. The decision to compile only maps of 3 and 6 months related to the time-lag between the start of the irrigation season and the end of the summer ( 6 months), but more maps could have been generated to give a better impression of the effect of groundwater extraction on the river 
flow during the irrigation season. According to the researchers, the model was still in the initial phase of its construction; therefore, the real effect of these restrictions (i.e., the absolute contribution of the Public Offer for the Acquisition of Water Rights to the flow in the Júcar River in 2007 and 2008) was not assessed.

Although the researchers indicated that there were many inaccuracies in the model and, the results could not be utilized in other situations, the $\mathrm{CHJ}$ used the results of the model by drawing the boundaries of the zone consistent with the iso-influence lines of the map (Figure A4). The map was used at meetings with farmers to legitimize policy decisions by explaining and visualizing how the Public Offer for the Acquisition of Water Rights zone was delineated. The farmers from JCRMO accepted that the farmers inside the "compensation zone" (where pumping would affect the river discharge after 6 months) would be eligible for compensation for refraining from irrigation, while farmers outside the "compensation zone" could not opt for compensation when refraining from irrigation. In 2007, some $28 \mathrm{Mm}^{3}$ groundwater use rights were bought (and thus the groundwater was left in the ground and the right holder compensated), at a total cost of 5.5 M euro. In 2008, some $51 \mathrm{Mm}^{3}$ of groundwater use rights was purchased at a total cost of $12.7 \mathrm{M}$ euro.

This policy measure was considered successful, as there was sufficient environmental flow in the Júcar River and a sufficient amount of water in the river for downstream users in the dry years 2007 and 2008. The CHJ and JCRMO attributed a large portion of the success regarding the Public Offer for the Acquisition of Water Rights to the use of the model, which predicted sufficient flow in the river by compensating farmers in the "compensation zone" and allowed the CHJ to make decisions that could easily be explained to water users and were therefore easily accepted. However, the outcomes of the MOA model and the Public Offer for the Acquisition of Water Rights 
policy were uncertain in terms of the decisions about the location and size of the boundaries of the zone, which were based on practical considerations of the researchers (ease of modelling the area) and the policy considerations of the CHJ (amount of funds available for compensation).

As the model determined which farmers could or could not obtain compensation for not using groundwater depending on their location, the model had a socio-economic effect on the farmers. Because compensation was near the net profit made with irrigated crops, the compensation for not irrigating reduced the risk inherent to agriculture but did not affect average incomes; however, the suppliers of the agricultural inputs and the postharvest companies suffered losses because of the reduced irrigation area. Estimating the costs suffered by these companies is difficult, but based on the assumptions made by Kahil et al. (2017), the deprived turnover for the agricultural service companies can roughly be estimated to be approximately 3 million euro for 2007 and 9 million euro for 2008.

In summary, the use of the MOA model for the Public Offer for the Acquisition of Water Rights had three main effects: the model legitimized the location of the "compensation zone" in the eyes of the farmers, the Jucar river had sufficient discharge in the dry summers of 2007 and 2008, and service companies in the "compensation zone" suffered financial losses. The effect of the use of water from an individual well could not be calculated and thus not compensated. A model with other characteristics would probably have determined the "compensation zone" in another location, shifting the economic effects to other farmers and agricultural providers, and most likely also changing the effect of the compensation on the Jucar River discharges.

Figure A4 near here 


\section{Selection of areas for the substitution of groundwater pumping with surface water use}

The second use of the MOA model was the selection of areas for substitution of groundwater use with surface water. The model used for the substitution of groundwater is very similar to the version used to analyse the Public Offer for the Acquisition of Water Rights. In fact, the model of the Public Offer for the Acquisition of Water Rights is similar to a zoom of the general model. Both models share the same parameters and boundary conditions, in addition to their geometry. The annual groundwater exploitation values from the MOA exceed the annual recharge value. With the goal of reaching a sustainable groundwater system while also maintaining irrigation in the MOA area, the Júcar River Basin Management Plan approved substitution of part of the groundwater extraction that is currently used for irrigation with surface water from the upper basin of the Júcar River (partly from the Tagus-Segura water transfer). For the distribution of surface water, channel systems in the areas of the Llanos de Albacete and La Herrera will be used (Figure 5). As established and approved by Real Decreto 1 on 8 January 2016, the Júcar River Basin Management Plan allocated a maximum of $80 \mathrm{Mm}^{3} / \mathrm{yr}$ of surface water to replace groundwater in the irrigated area of the MOA. The objectives of this replacement were to (1) restore Júcar River flows, (2) increase the buffering capacity of the MOA, and (3) reduce energy costs associated with groundwater pumping by increasing the piezometric water level, as the increased depth of groundwater causes the energy use from pumps to increase (Irles, 2007).

The CHJ and JCRMO wanted the MOA model to assist in the selection of areas where groundwater substitutions would be the most beneficial and to predict the effects of the measured piezometric levels on the river-aquifer relationship. The CHJ and 
JCRMO selected four potential areas for pumping substitutions, with an approximate surface area of $109.5 \mathrm{~km}^{2}$. These areas were near possible superficial water intakes, such as those in the Júcar River or the Tajo-Segura transfer system. In each area, approximately $10 \mathrm{Mm}^{3} /$ year of groundwater extraction would be replaced by surface water (Figure 5).

Figure 5 near here

Based on the demands of policy makers, the university researchers performed a series of model runs either with or without pumping substitutions, in which the groundwater flow was simulated from 2015 to 2027; this period was set by the Water Framework Directive as the time required to reach a good status for groundwater bodies in the Júcar River basin. Achieving a good status for all water bodies by a set deadline was one of the key goals of the European Commission. The characteristics of the simulation were 1) fixed annual groundwater extraction rates ( $315 \mathrm{Mm}^{3} / \mathrm{yr}$ annually) and 2) fixed annual groundwater recharge values (from the Patrical model), which were based on a 1980-2014 analysis. Groundwater extraction in the areas selected for pumping substitutions decreased in the model (with a maximum decrease in groundwater use of 10 $\mathrm{Mm}^{3} /$ year). For each of the simulated scenarios (i.e., for each area), the results of the modelling project were presented in tables and graphs, which allowed for comparisons among different scenarios for groundwater substitution. The elements to be compared were the annual flow volume from the Júcar River to the aquifer, which was calculated at different river sections, the monthly piezometric water levels and the annual mean static water levels in areas where pumping substitutions occurred (see Cassiraga et al. (2014) for detailed results).

The results were used by the $\mathrm{CHJ}$ to establish priorities in policy-making using additional information, such as planned infrastructures and the economic and technical 
viabilities of these projects. In this case, the model had an operative function that facilitated decision-making within the pre-established parameters and guidelines from the previously determined policy choices. In this manner, the modelling process legitimized the substitution policy, which was controversial because water transfer from the Tagus received a substantial amount of criticism from environmental organizations (HernándezMora et al., 2014), and the required infrastructure to transport surface water to farms would be expensive (Euro 80 million) (Irles, 2007). Alternatively, the model could also be used to assess and visualize the environmental and economic effects of the water transfer to the Júcar River in the Tagus basin (the origin of the water) and the Segura basin (the original destination of the water). By not taking these effects into account, the model itself influenced the debate about the groundwater substitution programme.

\section{Conclusions}

Groundwater model outcomes are not a direct representation of the hydrological reality; rather, they only present a limited, uncertain and imprecise simplification of that reality. Many factors might be excluded (e.g., aquifer interaction, human action, future generations and climate change trends), data sets might be limited, and arbitrary choices might be made for system boundaries, temporal and geographic scales and model parameters to simplify the model. Some stakeholders might have a considerable stake in aspects that were left out of the model. Moreover, commissioners steer the model in a certain direction by requiring certain outcomes. This process is referred to as the social construction of groundwater models in the SCOT approach. Groundwater models are tools that have certain characteristics and functions (i.e., requirements for use in terms of

the SCOT approach). They enable and constrain the functions and possible outcomes of the use of a model and thus influence the distribution of benefits and negative effects for 
different social groups and environment. The social status of models and the habit of disregarding many uncertainties in the model outcomes contribute to the policylegitimizing effect of model use. These are termed social consequences of the model use in the SCOT approach.

Our analysis of the MOA groundwater model in Spain using the SCOT approach shows the social, economic and environmental consequences of the use of a hydrological model. We show how modelling the MOA formed part of the policy processes used by water authorities, which were developed in response to upstream-downstream conflicts in the Júcar River basin and required more insight regarding the interactions between the MOA and the Júcar River. In 2006, the water authorities commissioned the modelling of the MOA to two universities in order to better inform their policy choices and gain legitimacy for those choices amongst involved stakeholders. Involving both an upstream university (Albacete) and a downstream university (Valencia) was a strategically crucial policy choice that legitimized the modelling in the eyes of both upstream and downstream stakeholders.

This model was crafted using available data and models, in addition to key decisions made by the modellers from the universities in collaboration with the policymakers from the CHJ. Those decisions were shaped by the interactions between the commissioners and the model makers regarding their visions, their knowledge and the data that they had at their disposal. By showing what choices were made in the modelling project, and by whom they were made, we highlight that developing the model and the choices made in the process were not only informed by modelling decisions of the model makers but also importantly by policy actors, their policy objectives, and interactions between model makers and policy makers. The mutual development of the outcome perceptions (and the spatial-temporal accuracy desired) forced the generation of the 
hydrological model regarding the given policy use. As such, the model was made to serve the political interests of the $\mathrm{CHJ}$ in terms of legitimizing and implementing policy-making regarding water users in both the upstream and downstream areas of the Júcar River basin.

In terms of the temporary water right purchase programme and the groundwater substitution programme, we show how the model outcomes were used to inform and legitimize policy design. By not taking into account the effects of the groundwater substitution programme in the Tagus and Segura river basins, the model results only visualized a partial view of the effects. Thus, it is clear that the specific configuration of the model and the used parameters changed not only the result of the model but also the use that can be given or how it is seen by users and other stakeholders. Despite the many limitations and uncertainties identified by the modellers, in both cases, the water authorities used the modelling outcomes as objective facts that informed and legitimized their policies. These same outcomes were also presented to stakeholders as proof of the objectivity in policy choices, which led to less resistance towards these policies.

In the studied case, the model was explicitly developed to support and legitimize the Public Offer for the Acquisition of Water Rights and the groundwater substitution measures of the CHJ. The environmental effect of the Public Offer for the Acquisition of Water Rights was that the Jucar River had an environmental flow in the dry summers of 2007 and 2008. The socio-economic effect of the programme was primarily the negative effect for the agricultural service companies (in total, some roughly estimated 3 and 7 million euros less turnover in each year of the compensation programme). The social, economic and environmental effect of the groundwater substitution programme was that water from the highly debated Tagus-Segura transfer could be used in the Júcar basin, affecting the potential users in the Tagus and Segura river basins. 
In conclusion, hydrological models are not neutral tools that enable policy makers to calculate effects of policies. We contend that because model development is an intrinsically social process that requires stakeholders to make choices that suit their own imaginations, interests and objectives, we must better understand these social processes to clarify the social construction of models. This is important because these choices affect the model outcomes and how they are translated into policies by specific actors, which have important environmental consequences and influence who benefits and/or who is negatively affected by these policies (Beall \& Ford, 2012; Budds, 2009; Forsyth, 2004),

This does not imply that the use of hydrological models in policy-making should be discredited. Models are extremely useful tools for exploring our understanding of socio-natural systems; they support policy making and help envisage possible impacts from certain policy implementation. However, we call for a deeper recognition and exploration of the processes involved in the creation of models, the presentation of results, and their use for policy design, legitimatization and acceptance. As a result, models and their role in the governmental domain should receive explicit attention. We therefore recommend that the goals and assumptions of models be explicitly defined and discussed with stakeholders, and stakeholders should be encouraged to discuss their ideas and knowledge with model and policy makers. This would facilitate more democratic policy making in water resource management.

\section{Acknowledgements}

This work was carried out as part of the collaboration agreement between the University of Castilla - La Mancha and Wageningen University. The research is also part of Femke Rambags' MSc Thesis. David Sanz was supported by the Grants for stays at other universities and research centres (UCLM). Special thanks go to the Júcar Water Authority (CHJ) and stakeholders (JCRMO) in the Mancha Oriental System for providing the necessary information. In addition, 
we would like to thank Dr. A. Sahuquillo of the Universitat Politècnica de València de Valencia and Dr. S. Castaño of the University of Castilla - La Mancha for comments and participation in the first stage of modelling. The contents of this paper do not represent the views of the CHJ and JCRMO. Finally, we thank the two anonymous reviewers of this article for their valuable comments and suggestions.

\section{References}

Anderson, M.P., Woessner, W.W., \& Hunt, R.J. (2015). Applied groundwater modeling: simulation of flow and advective transport. Academic press.

Beall, A.M., \& Ford, A. (2012). Reports from the field: assessing the art and science of participatory environmental modeling, in: Societal Impacts on Information Systems Development and Applications. IGI Global, pp. 195-213.

Beven, K. (2000). On model uncertainty, risk and decision making. Hydrological Processes, 14(14), 2605-2606. _ https://doi.org/10.1002/1099-1085(20001015)14:14<2605::AID$\underline{\mathrm{HYP} 400>3.0 . \mathrm{CO} ; 2-\mathrm{W}}$

Bijker, W.E. (1987). Social construction of technology. Wiley Online Library.

Bijker, W.E., Hughes, T.P., Pinch, T., \& Douglas, D.G. (2012). The social construction of technological systems: New directions in the sociology and history of technology. MIT press.

Bots, P., Bijlsma, R., von Korff, Y., Van der Fluit, N., \& Wolters, H. (2011). Supporting the constructive use of existing hydrological models in participatory settings: a set of "rules of the game". Ecology and Society, 16(2). https://www.ecologyandsociety.org/vol16/iss2/art16/main.html

Budds, J. (2009). Contested H 2 O: science, policy and politics in water resources management 
in Chile. Geoforum 40, 418-430. https://doi.org/10.1016/j.geoforum.2008.12.008

Burke, J.J., \& Moench, M.H. (2000). Groundwater and society: resources, tensions and opportunities. Themes in groundwater management for the twenty-first century. Department of International Economic and Social Affairs, Statistical Office, United Nations.

Calera, A., Garrido-Rubio, J., Belmonte, M., Arellano, I., Fraile, L., Campos, I., \& Osann, A. (2017) Remote sensing-based water accounting to support governance for groundwater management for irrigation in la Mancha Oriental Aquifer, Spain. Wit transactions on ecology and the environment. 220: 119-126.

Cassiraga, E., Sanz, D., Castaño, S., Álvarez, \& O., Sahuquillo, A. (2013). Modelo de flujo subterráneo de los acuíferos de la Mancha Oriental y sus relaciones con el río Júcar [Groundwater model flow of the Mancha Oriental Aquifer and their relations with the Júcar River]. Unpublished report. pp 77. Confederación Hidrográfica del Júcar.

Cassiraga, E., Sanz, D., Castaño, S., Estrela, T., \& Irles, D. (2014). Evaluación del impacto de las sustituciones de bombeo en el comportamiento hidrogeológico del Sistema de la Mancha Oriental [Assessment of the impact of pumping substitutions on the hydrogeological behavior of Mancha Oriental System], in: Gómez-Hernández, J., Rodrigo-llarri, J. (Eds.), II Congreso Ibérico de las aguas subterráneas. Ed. Universitat Politècnica de València, Valencia, pp. 163-172.

Castaño, S., Sanz, D., \& Gómez-Alday, J. J. (2010). Methodology for quantifying groundwater abstractions for agriculture via remote sensing and GIS. Water Resources Management, 24(4), 795-814. https://doi.org/10.1007/s11269-009-9473-7

Castilla-Rho, J. C. (2017). Groundwater modeling with stakeholders: Finding the complexity that matters. Groundwater, 55(5), 620-625. https://doi.org/10.1111/gwat.12569

Chiang, W.-H., Kinzelbach, W., \& Rausch, R. (1998). Aquifer simulation model for Windows: 
groundwater flow and transport modeling, an integrated program. G. Borntraeger.

CHJ (2014). Confederación Hidrográfica del Júcar. Plan Hidrológico de la Cuenca del Júcar 2009-2015 [Júcar River Basin Management Plan 2009-2015]. Ministerio de Medioambiente. http://www.chj.es/es-es/medioambiente/planificacionhidrologica/Paginas/PHC-2009-2015$\underline{\text { Indice.aspx }}$

CHJ (2016). Confederación Hidrográfica del Júcar. Plan Hidrológico de la Cuenca del Júcar 2015-2021[Júcar River Basin Management Plan 2015-2021]. Ministerio de Medioambiente. http://www.chj.es/es-es/medioambiente/planificacionhidrologica/Paginas/PHC-2015-2021$\underline{\text { Indice.aspx }}$

Doherty, J., \& Simmons, C. T. (2013). Groundwater modelling in decision support: reflections on a unified conceptual framework. Hydrogeology Journal, 21(7), 1531-1537. https://doi.org/10.1007/s10040-013-1027-7

EC (2000). Directive 2000/60/EC of the European Parliament and of the Council, of 23 October 2000, establishing a framework for Community action in the field of water policy. Official Journal of the European Commission, L 327/1, 22.12.2000

Ferrer, J. \& Garijo, L. (2013). Mercados del agua y flexibilización del marco concesional [Water markets and flexibilization of the concessional framework]. XI Semin. Nac. "Transparencia y concesiones" Obs. del Agua la Fund. Botín.

Forsyth, T. (2004). Critical political ecology: the politics of environmental science. Routledge.

Giordano, M. (2009). Global groundwater? Issues and solutions. Annual review of Environment and Resources, 34, 153-178. https://doi.org/10.1146/annurev.environ.030308.100251

GWP (2000). Integrated water resources management. TAC Backgr. Pap.

Harbaugh, A.W., Banta, E.R., Hill, M.C., \& McDonald, M.G. (2000). MODFLOW-2000, The U. 
S. Geological Survey Modular Ground-Water Model-User Guide to Modularization Concepts and the Ground-Water Flow Process. Open-file Report. U. S. Geol. Surv. 134.

Hernández-Mora, N., del Moral Ituarte, L., La-Roca, F., La Calle, A., \& Schmidt, G. (2014). Interbasin water transfers in Spain: Interregional conflicts and governance responses. In Globalized Water (pp. 175-194). Springer Netherlands.

Hill, M.C., Middlemis, H., Hulme, P., Poeter, E., Riegger, J., Neumann, S., Williams, H., \& Anderson, M. (2015). Brief overview of selected groundwater modeling guidelines. FEMModflow, in: International Conference on Finite Element Models, Modflow and More.

Holley, C., Sinclair, D., Lopez-Gunn, E., \& Schlager, E. (2016). Conjunctive Management Through Collective Action, in: Integrated Groundwater Management. Springer, pp. 229252.

Hoogesteger, J., \& Wester, P. (2015). Intensive groundwater use and (in) equity: Processes and governance challenges. Environmental Science \& Policy, 51, 117-124. https://doi.org/10.1016/j.envsci.2015.04.004

Hoogesteger, J., \& Wester, P. (2017). Regulating groundwater use: The challenges of policy implementation in Guanajuato, Central Mexico. Environmental Science \& Policy, 77, 107113. https://doi.org/10.1016/j.envsci.2017.08.002

Irles, D. (2007). Proyecto informativo de sustitución de bombeos en el Acuífero de la Mancha Oriental, Fase II [Pumping replacement information project in the Mancha Oriental Aquifer Phase II]. http://www.mapama.gob.es/es/agua/planes-y-estrategias/informes-deviabilidad-de-obrashidraulicas/759 CHJ A. sustitucion bombeo acuifero manchaoriental faseII tcm7164195.pdf Access 12/04/2017.

Jakeman, A.J., Barreteau, O., Hunt, R.J., Rinaudo, J.-D., Ross, A., Arshad, M., \& Hamilton, S. (2016). Integrated Groundwater Management: An Overview of Concepts and Challenges, in: 
Integrated Groundwater Management. Springer, pp. 3-20.

Kahil, M. T., Ward, F. A., Albiac, J., Eggleston, J., \& Sanz, D. (2016). Hydro-economic modeling with aquifer-river interactions to guide sustainable basin management. Journal of Hydrology, 539, 510-524. https://doi.org/10.1016/j.jhydrol.2016.05.057

King, J.L., \& Kraemer, K.L. (1993). Models, facts, and the policy process: the political ecology of estimated truth. Cent. Res. Inf. Technol. Organ.

Konikow, L. F., \& Bredehoeft, J. D. (1992). Ground-water models cannot be validated. Advances in Water Resources, 15(1), 75-83. https://doi.org/10.1016/0309-1708(92)90033-X

Konikow, L. F., \& Kendy, E. (2005). Groundwater depletion: A global problem. Hydrogeology Journal, 13(1), 317-320. https://doi.org/10.1007/s10040-004-0411-8

Ley 29/1985 de Aguas, August, $2^{\text {nd }} 1985$. [Spanish Water Law of 1985]. BOE-189, 8/81985, Madrid pp. 25123-25135. Repealed by Ley 46/1999, December, 13 rd 1999. Currently addresses to: Real Decreto Legislativo $1 / 2001$, July, $20^{\text {th }} 2001$, which approves the Revised Text of the Spanish Water Law.

Lopez-Gunn, E. (2003). The role of collective action in water governance: A comparative study of groundwater user associations in La Mancha aquifers in Spain. Water International, 28(3), 367-378. http://dx.doi.org/10.1080/02508060308691711

Massuel, S., Cappelaere, B., Favreau, G., Leduc, C., Lebel, T., \& Vischel, T. (2011). Integrated surface water-groundwater modelling in the context of increasing water reserves of a regional Sahelian aquifer. Hydrological Sciences Journal, 56(7), 1242-1264. http://dx.doi.org/10.1080/02626667.2011.609171

Melsen, L.A., Addor, N., Mizukami, N., Newman, A.J., Torfs, P.J., Clark, M.P., Uijlenhoet, R. and Teuling, A.J. (2018). Mapping (dis) agreement in hydrologic projections. Hydrology and Earth System Sciences, 22(3), 1775-1791. http://dx.doi.org/10.5194/hess-22-1775-2018 
Molle, F. (2008). Why enough is never enough: The societal determinants of river basin closure. International Journal of Water Resources Development, 24(2), 217-226. http://dx.doi.org/10.1080/07900620701723646

Narain, V., \& Singh, A.K. (2017). Flowing against the current: The socio-technical mediation of water (in) security in periurban Gurgaon, India. Geoforum 81, 66-75. https://doi.org/10.1016/j.geoforum.2017.02.010

Pérez, M.A. (2005). Modelo distribuido de simulación del ciclo hidrológico con calidad de aguas integrado en sistemas de información geográfica para grandes cuencas [Distributed model of simulation of the hydrological cycle with water quality integrated in geographic information systems for large basins]. Ph.D. Thesis, Universidad Politécnica de Valencia, Spain.

Rambags F. (2014). The social shaping of the hydrological model of the Mancha Oriental System. Msc Thesis Water resources management. Wageningen University.

Real Decreto $1 / 2016$, January, $8^{\text {th }}$ 2016, approving the revision of the Hydrological Plans of the Spanish River Basin Districts. BOE-16, 19/01/2016, Madrid pp.2972-4301.

Refsgaard, J. C., \& Henriksen, H. J. (2004). Modelling guidelines-terminology and guiding $\begin{array}{llll}\text { principles. Advances in } & \text { W1-82. }\end{array}$ https://doi.org/10.1016/j.advwatres.2003.08.006

Sanz, D., Calera, A., Castaño, S., \& Gómez-Alday, J.J. (2016). Knowledge, participation and transparency in groundwater management. Water Policy 18. https://doi.org/10.2166/wp.2015.024

Sanz, D., Castaño, S., Cassiraga, E., Sahuquillo, A., Gómez-Alday, J. J., Peña, S., \& Calera, A. (2011). Modeling aquifer-river interactions under the influence of groundwater abstraction in the Mancha Oriental System (SE Spain). Hydrogeology Journal, 19(2), 475-487. https://doi.org/10.1007/s10040-010-0694-x 
Sanz, D., Gómez-Alday, J. J., Castaño, S., Moratalla, A., De las Heras, J., \& Martínez-Alfaro, P. E. (2009). Hydrostratigraphic framework and hydrogeological behaviour of the Mancha Oriental System (SE Spain). Hydrogeology Journal, 17(6), 1375-1391. https://doi.org/10.1007/s10040-009-0446-y

Tortajada, C. (2010). Water governance: Some critical issues. International Journal of Water Resources Development, 26(2), 297-307. http://doi.org/10.1080/07900621003683298

Vaux, H. (2011). Groundwater under stress: the importance of management. Environmental Earth Sciences, 62(1), 19-23. https://doi.org/10.1007/s12665-010-0490-x

Voinov, A., \& Bousquet, F. (2010). Modelling with stakeholders. Environmental Modelling \& Software, 25(11), 1268-1281. https://doi.org/10.1016/j.envsoft.2010.03.007

Voinov, A., Kolagani, N., McCall, M.K., Glynn, P.D., Kragt, M.E., Ostermann, F.O., Pierce, S.A., \& Ramu, P. (2016). Modelling with stakeholders-next generation. Environmental Modelling \& Software, 77, 196-220. https://doi.org/10.1016/j.envsoft.2015.11.016

Voss, C. I. (2011). Editor's message: Groundwater modeling fantasies-part 1, adrift in the details. Hydrogeology Journal, 19(7), 1281-1284. https://doi.org/10.1007/s10040-011-0789$\underline{\mathrm{Z}}$

Wester, P., Hoogesteger, J., \& Vincent, L. (2009). Local IWRM organizations for groundwater regulation: The experiences of the Aquifer Management Councils (COTAS) in Guanajuato, Mexico, in: Natural Resources Forum. Wiley Online Library, pp. 29-38. 


\section{FIGURE CAPTIONS}

Figure 1. Location of study area. Simplified hydrogeological map of Mancha Oriental Aquifer (MOA). JRB: Júcar River Basin; HU: Hydrogeological Unit. Dashed line: perimeter of the Public Offer for the Acquisition of Water Rights see Figure 4.
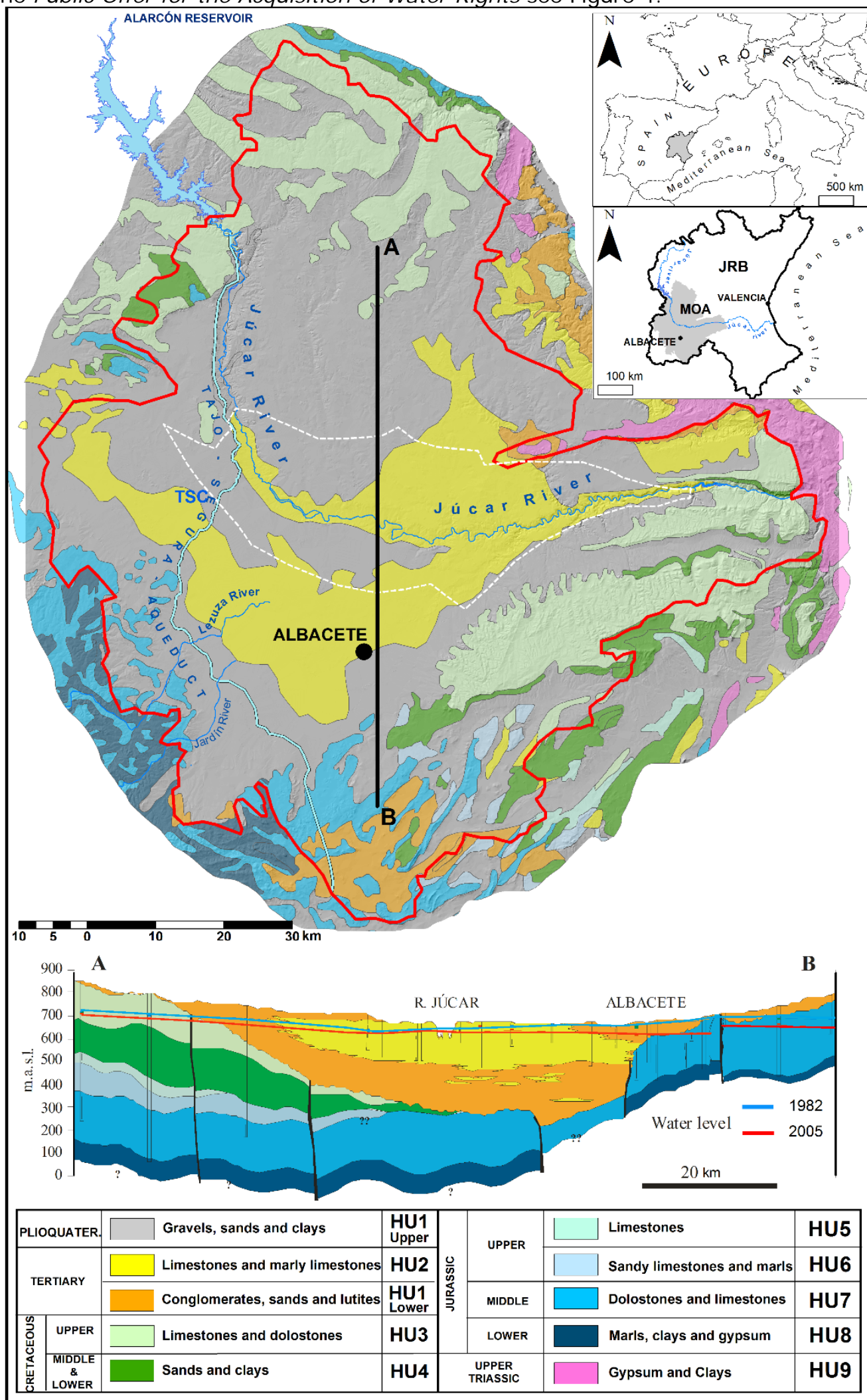
Figure 2. Groundwater modelling process with variables and their computational relationships modified from Bots et al. (2011); Refsgaard and Henriksen (2004); and Voinov et al. (2016). The participatory modelling process (conceptual model-code selectionparametrization-calibration and validation) is used for decision making and is adaptable to the evolving needs presented by the modelled management action and by the interests of the relevant social groups within a general or wider context. The different components can be revised as needed.

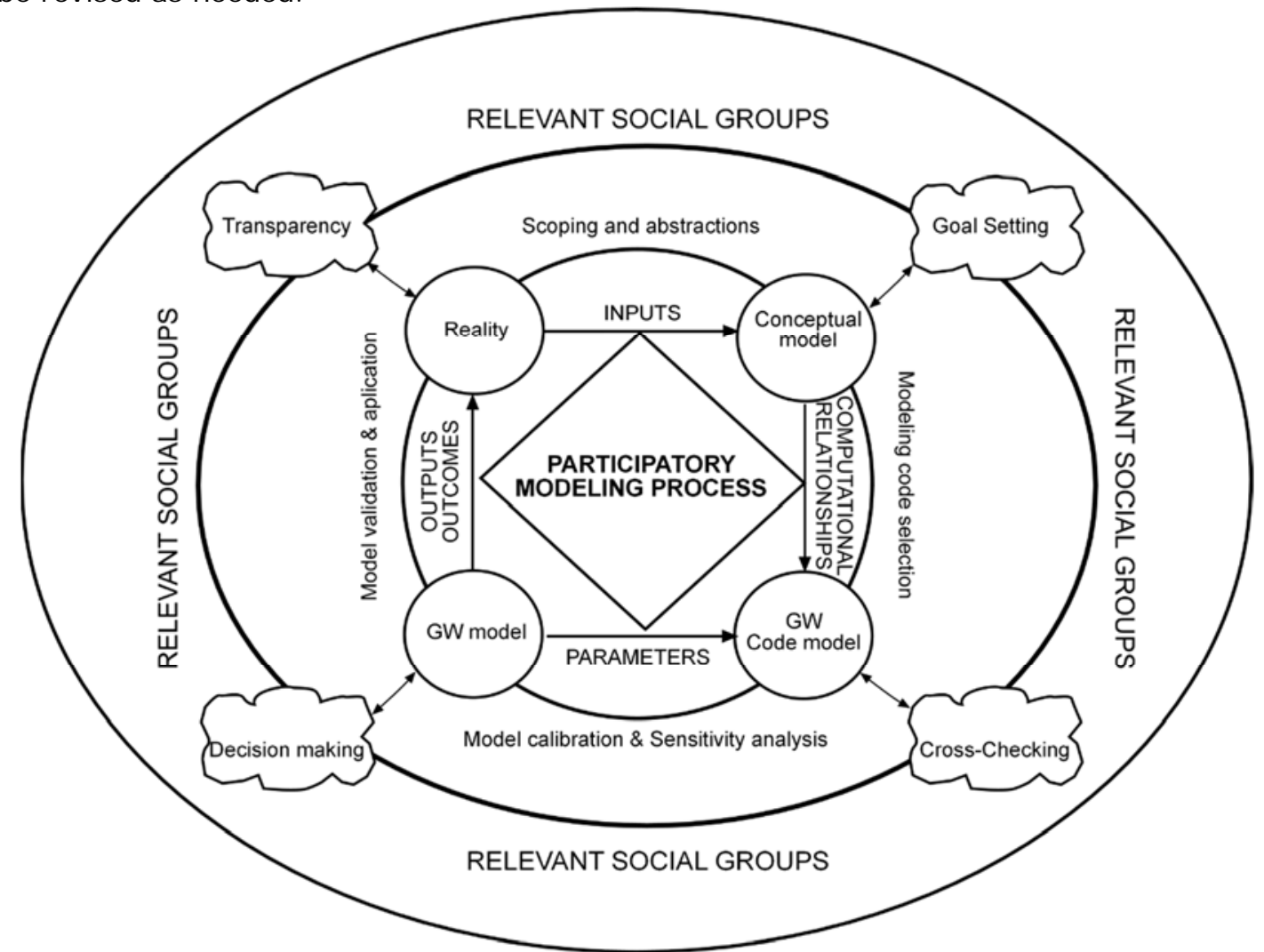

WIDER CONTEXT 
Figure 3. Evolution of groundwater pumping and aquifer discharge by the Júcar River (Top). Cumulative groundwater storage evolution (Bottom).
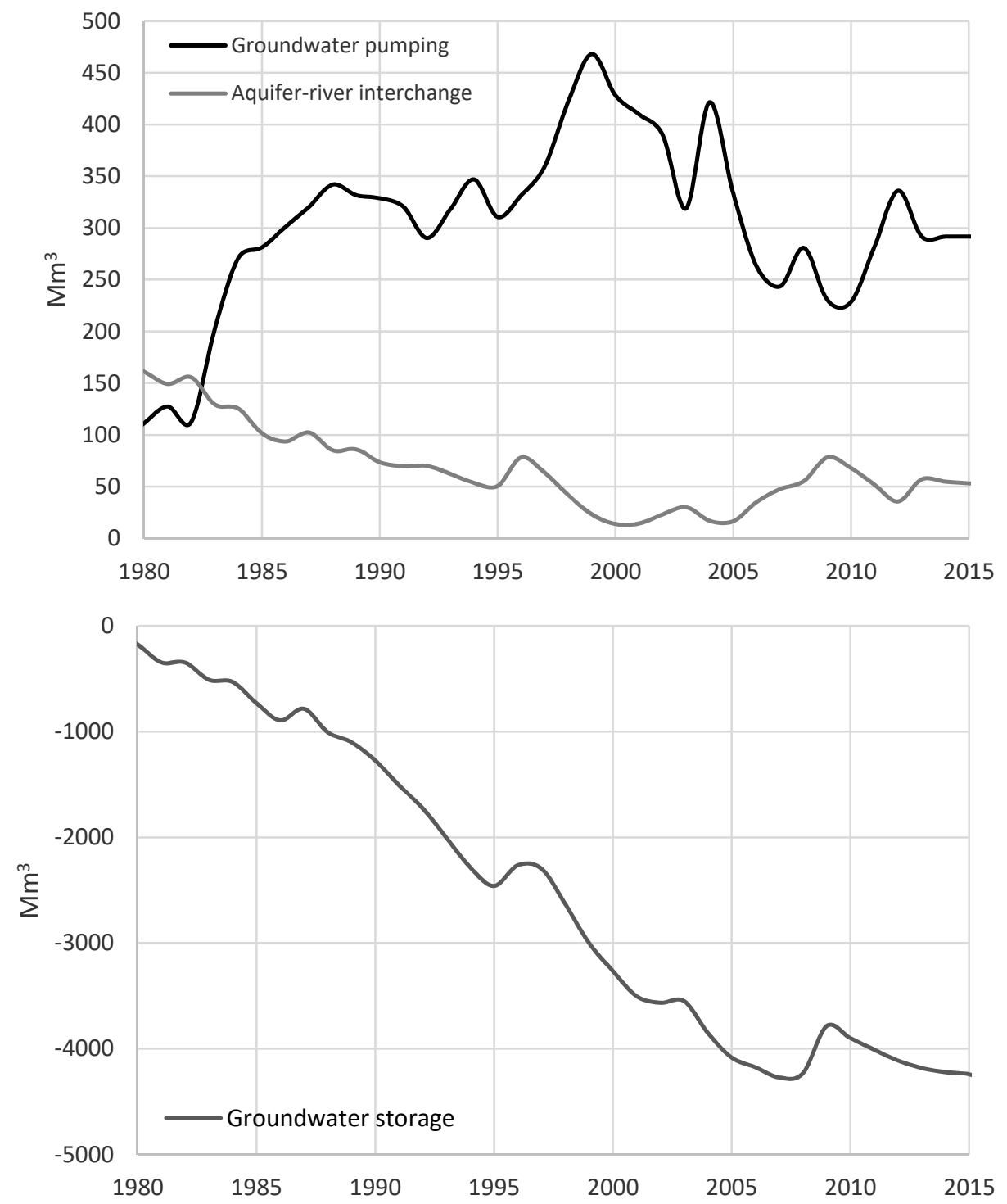
Figure 4. Isotransmissivity map resulting from modelling showing the zone of greatest pumping influence on the flows of the Júcar River within the territorial scope of the perimeter of the public Offer for the Acquisition of water rights (dashed line). The iso-line indicates the amount of river water withdrawals as a percentage of groundwater withdrawals after a period of 3 months of continuous pumping. The location of middle Miocene Aquifer in Mancha Oriental Aquifer can be seen in Figure 1. Source: BOE no 312, 20/12/2006 and modified from (Ferrer and Garijo, 2013).

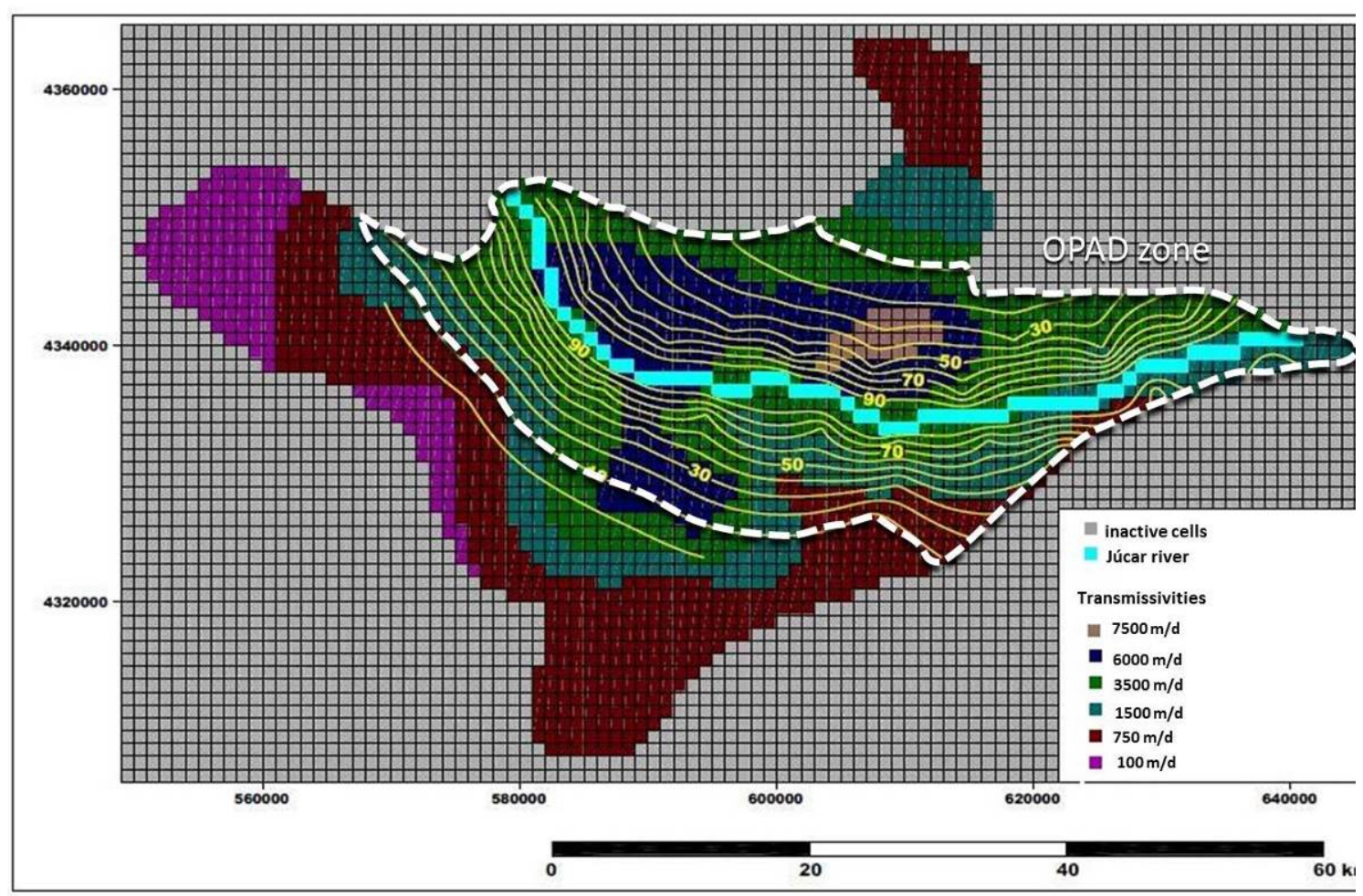


Figure 5. Location of possible substitution areas for subsurface water pumping (grey coloured areas).

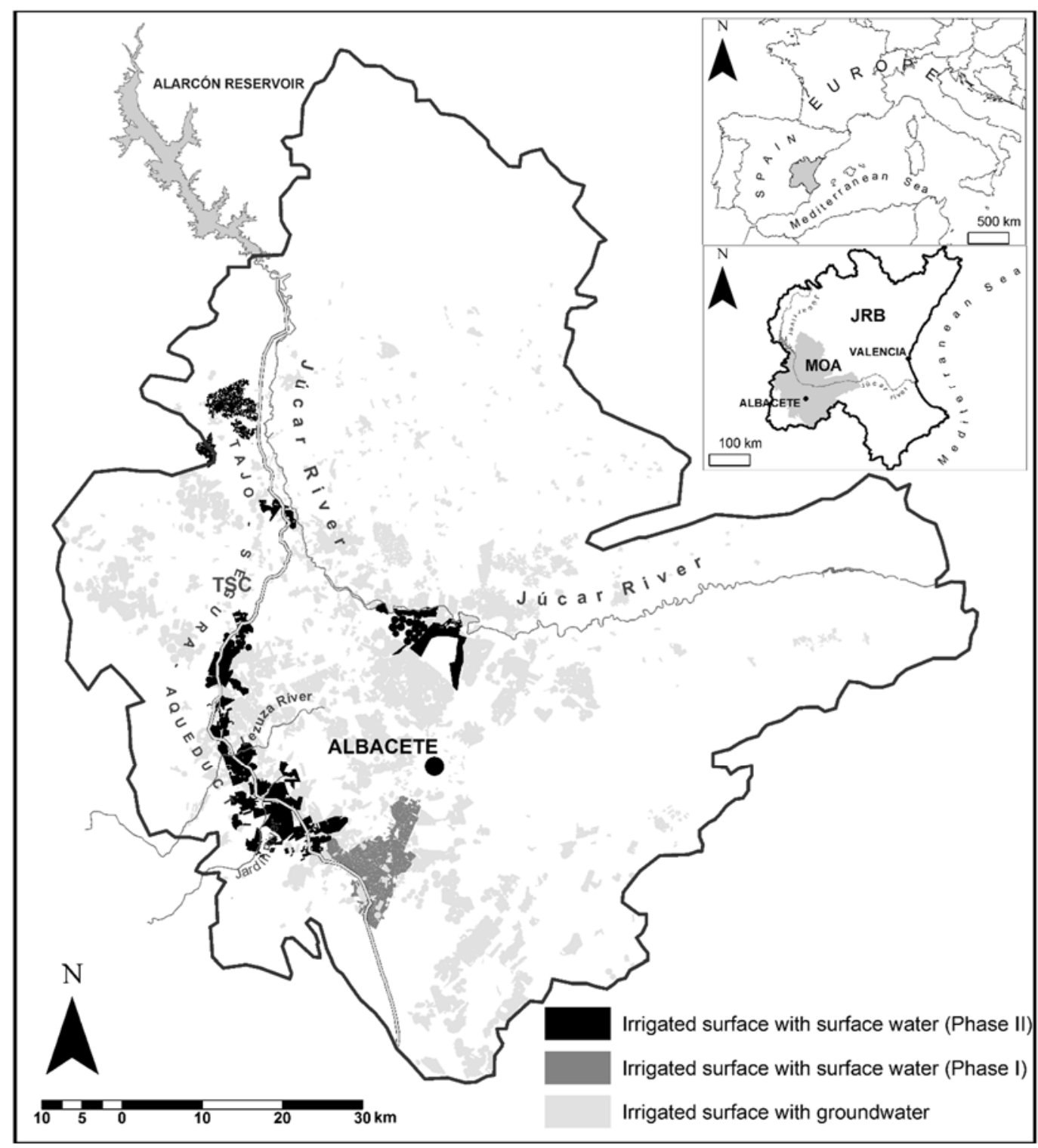


TABLE CAPTIONS 
Table 1. Trajectories available and selection in Mancha Oriental Groundwater model in pro-active use of SCOT. To follow guidelines of the modelling process we have modified from ((Anderson et al., 2015; Chiang et al., 1998). All parameters are verified and calculated by scientifically endorsed methods.

\begin{tabular}{|c|c|c|c|}
\hline \multicolumn{3}{|c|}{ Aspects \& Variables } & Descriptions: Trajectories, closure \& stabilization \\
\hline \multicolumn{3}{|c|}{$\begin{array}{l}\text { Understanding of the groundwater system. } \\
\text { Estimation of aquifer properties. } \\
\text { Understanding the past, the present, and } \\
\text { Forecasting the future. }\end{array}$} & $\begin{array}{l}\text { Agreement between JCRMO-CHJ-Universities. 1. To understand the general behaviour of the MOA- Júcar River relationship. Calibration for } \\
\text { the period 1940-1980 and 1980-2012. Validation 2012-Today. 2. Planning scenarios according to planning horizon 2026-2027 by modifying } \\
\text { groundwater pumping and recharge conditions. 3. Management scenarios according to JRMP. Needs i.e., a) OPAD, b) Groundwater pumping } \\
\text { substitutions. }\end{array}$ \\
\hline \multirow{7}{*}{$\stackrel{\Xi}{\Xi}$} & \multirow{4}{*}{ 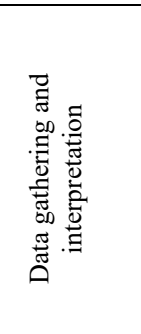 } & Geometry & Selected by researchers based on previous studies. No discussion. \\
\hline & & Aquifer parameters & Selected by researchers based on previous studies. No discussion. \\
\hline & & $\underline{\text { Outflows }}$ & $\begin{array}{l}\text { Groundwater pumping: Selected by JCRMO. Groundwater pumping is obtained according to Castaño et al. (2013). Water requirements of crops } \\
\text { were configured by irrigators as an average year-on-year value. } \\
\text { River discharge and boundary flows: Agreement between JCRMO-CHJ-Universities. There was uncertainty in observed river discharge data. } \\
\text { It was proposed to analyse different reaches of the river with associated projects. }\end{array}$ \\
\hline & & $\underline{\text { Inflows }}$ & $\begin{array}{l}\text { Groundwater Recharge: Selected by CHJ. Values came from another CHJ model and could not be calibrated } \\
\text { Boundary flows: Selected by CHJ. Conditions imposed by planning. } \\
\text { Infiltration from river: Obtained by universities based on calibration. No discussion. }\end{array}$ \\
\hline & \multirow{3}{*}{ 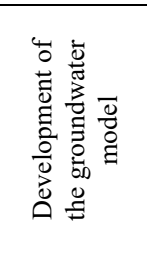 } & $\begin{array}{l}\frac{\text { Characterization of aquifers }}{\text { Hydrogeological units-Model domain }} \\
\text { Grid size (horizontal/vertical) }\end{array}$ & $\begin{array}{l}\text { Selected by researchers based on their experience and studies. No discussion. } \\
\text { Agreement between JCRMO-CHJ- Universities. One layer was chosen for each hydrogeological unit. Stakeholders better understood the model } \\
\text { by looking at hydrogeological cross sections. } \\
\text { Agreement between JCRMO-CHJ- Universities. A cell size of } \mathrm{km}^{2} \text { was established, minimum resolution for them that also converted a } \\
\text { heterogeneous medium as the karstification of the limestone in a homogeneous porous medium. }\end{array}$ \\
\hline & & Time discretization & Agreement between JCRMO-CHJ-Universities. A monthly time step was decided. \\
\hline & & Initial and boundary conditions & Selected by CHJ technicians. Conditions imposed by planning. (CHJ, 2014, 2016) \\
\hline $\begin{array}{l}\text { Computa- } \\
\text { tional } \\
\text { relation }\end{array}$ & $\begin{array}{c}\text { Code } \\
\text { selection }\end{array}$ & $\underline{\text { Finite differences }}$ & $\begin{array}{l}\text { Selected by universities. No discussion. In this case, the MODFLOW model was chosen because it is considered to be a suitable tool for } \\
\text { simulation (long-term average or time-varying conditions) of groundwater elevation, and discharge to, or from, surface water (as Júcar } \\
\text { River). }\end{array}$ \\
\hline \multirow{2}{*}{$\begin{array}{l}\text { Para- } \\
\text { meters }\end{array}$} & Calibration & $\underline{\text { Simulation observed data }}$ & Selected by universities and analysed by stakeholders. Hydraulic heads calibration, River flows. Method 1) Trial and error y 2) Automatic \\
\hline & Sensitivity & $\underline{\text { Uncertainty of parameters }}$ & $\begin{array}{l}\text { Selected by researchers and performed as scientific work. When the results were analysed, the users analysed the uncertainty of certain data } \\
\text { and proposed new work to reduce this uncertainty }\end{array}$ \\
\hline $\begin{array}{c}\text { Outputs } \\
\text { Out- } \\
\text { comes }\end{array}$ & Validation & $\begin{array}{l}\text { Predict existing conditions } \\
\underline{\text { Predict alternate conditions }} \\
\text { Presenting the model results }\end{array}$ & $\begin{array}{l}\text { Agreement between JCRMO-CHJ-Universities. Groundwater budgets and river-aquifer relationships were analysed in different periods, } \\
\text { looking for average values with which to negotiate allocations, etc. Once the agreement had been reached, the researchers prepared the final } \\
\text { report. }\end{array}$ \\
\hline
\end{tabular}


Table 2. Results from the Public Offer for the Acquisition of Water Rights (OPAD), for a total irrigated area of $280 \mathrm{~km}^{2}$ Source:(Ferrer and Garijo, 2013).

Applications submitted:

119 234

Volume in rights $\left(\mathrm{Mm}^{3}\right)$

56.8

109.6

Volume waived without

economic compensation

22.9

12.5

$\left(\mathrm{Mm}^{3}\right)$

Volume offered $\left(\mathrm{Mm}^{3}\right)$

27.3

50.6

Budget used (million Euro)

5.5

12.7

Reserved volume $\left(\mathrm{Mm}^{3}\right)$

6.6

46.5 